Original Research Paper

\title{
Geochemical and Petrology Properties of Zafarghand Index and Kahang Deposit of Porphyry Copper-Molybdenum
}

\author{
${ }^{1}$ Mohsen Dehghanipoodeh, ${ }^{1}$ Hooshang Asadi Haroni, \\ ${ }^{1}$ Mahin Mansouri Esfahani, ${ }^{2}$ Farzad Shafiei and ${ }^{3}$ Kaveh Ostad-Ali-Askari \\ ${ }^{I}$ Department of Mining Engineering, Isfahan University of Technology, Isfahan, Iran \\ ${ }^{2}$ Department of Art and Architecture, Islamic Azad University, Najafabad Branch, Isfahan, Iran \\ ${ }^{3 *}$ Department of Water Engineering, College of Agriculture, Isfahan University of Technology, Isfahan 8415683111, Iran
}

\author{
Article history \\ Received: 14-04-2018 \\ Revised: 30-05-2018 \\ Accepted: 18-11-2020 \\ Corresponding Author: \\ Kaveh Ostad-Ali-Askari \\ Department of Water \\ Engineering, College of \\ Agriculture, Isfahan University \\ of Technology, Isfahan \\ 8415683111, Iran \\ Email: ostadaliaskari.k@of.iut.ac.ir \\ kaveh.oaa2000@gmail.com
}

\section{Introduction}

Porphyry copper-molybdenum deposits have been known for the first time in the early decade of the twentieth century in North America. Since then, this term has been used for a wide range of dispersed sulfide deposits associated with intrusive bodies formed in orogeny belt. The composition of intrusive rocks from the porphyry copper-molybdenum deposit varies from acid to medium rocks. The most common combination of intrusive rocks is quartz-monzonite composition, however various compounds from syenite to diorite have also been seen (Karimpour et al., 2005). Generally, porphyry copper mineralization were made in the vicinity of granitic Miocene rocks in the central Iran's volcanic arc (Aliani et al., 2009). Magmatic activities and mineralization correlations in this arc are also related to the Zagros zone (Derakhshani and Abdolzadeh, 2009). Ever-increasing demand of the metals on the one hand and the reduction of the feasible and superficial sources of these elements on the other hand have caused the deeper reserves of these metals to be considered. The importance of porphyry type deposits as world sources of copper-molybdenum and valuable metals such as gold, silver, selenium, tellurium and rhenium, can justify the importance of exploration of this type of ore deposits (Kudrin et al., 1986). Prior studies associated with geological aspects in Kahang deposite were conducted; for instances in (Afzal et al., 2012; 2010), they studied various mineralization zones especially supergene enrichment and hypogene zones in Kahang deposit, based on analyzing 
the subsurface data using a proposed power spectrumvolume (P-V) fractal method. Yasrebi et al. (2012) various geological models of the eastern part of Kahang $\mathrm{Cu}-\mathrm{Mo}$ porphyry deposit were studied. The all alteration and zonation were separatedby $3 \mathrm{D}$ models of lithology and the alteration model further illustrates that there is an extensive phyllic alteration associated with the shallower potassic alteration to the west approaching the surface (Komeili et al., 2016). Yasrebi et al. (2013) identified the major mineralized zones including supergene enrichment and hypogene enrichment in the Kahang porphyry deposit.

In this study, not only the geological properties but also the geochemical properties such as study of geochemical anomalies of elements, determination of threshold values to separate anomalies from background using detachable statistics methods based on the probability distribution function and calculating correlation between chemical elements in order to clustering themhave been investigated. Eventually the anomaly maps of single and composite halos of copper and molybdenum were depicted to assign the enrichment zones in both Zafarghand index and Kahang deposit.

\section{The Introduction of Urumieh-Dokhtar Volcanic Arc}

The Urumieh-Dokhtar volcanic arc were formed by the subduction of the Neo-Tethys oceanic plate and subsequently the Arabic plate below Iran during the middle Miocene and its rocks are generally intermediate volcanic rocks and their pyroclastics. As shown in Fig. 1, this arc is along the strip with length of $1700 \mathrm{~km}$ and with a width of roughly 40 to $80 \mathrm{~km}$ which is parallel to the metamorphosed zones of Sanandaj-Sirjan and Zagros thrust and it has been stretched with a trend of northwest to southeast (Darvishzadeh, 1991). The thickness of crust in this zone is 45 to $50 \mathrm{~km}$ and is known as largest belt of copper in Iran. Because of the major copper deposits such as Sungun, Sarcheshmeh, Miduk and Darehzar are located in it. Creating this zone is mainly based on magmatic activities in Cenozoic and especially in the Neogen- Pleistocene. The location of both Zafarghand index and Kahang deposit of porphyry copper-molybdenum along with other porphyry copper deposits are shown in Fig. 1.

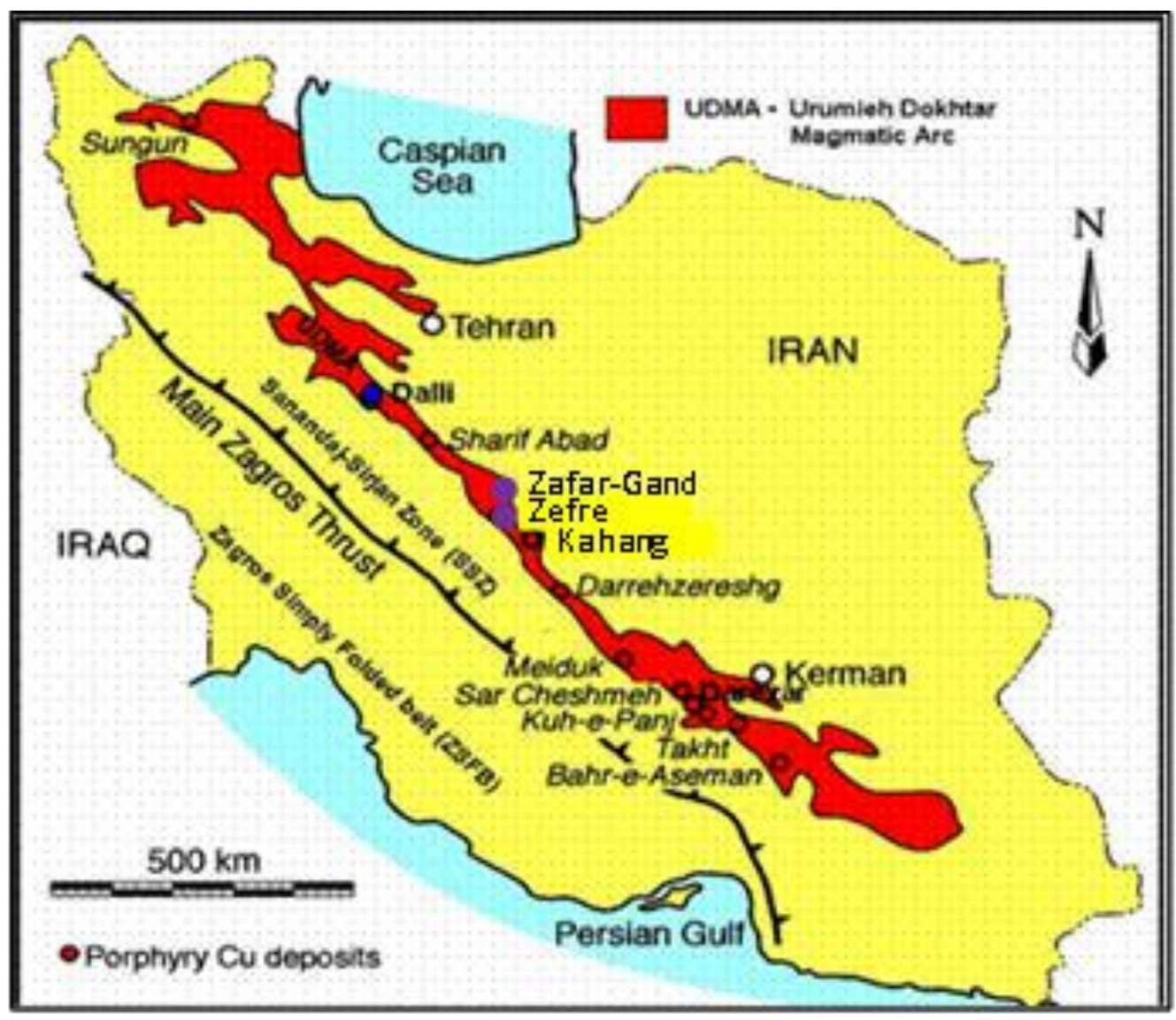

Fig. 1: Location of Urumieh-Dokhtar volcanic arc and Zafarghand index and Kahang deposit (Asadi Haroni, 2010; 2003) 


\section{Geology and Petrology of Zafarghand Index and Kahang Deposit of Porphyry Copper- Molybdenum}

Geographic Location and Geology of Zafarghand Index and Kahang Deposit

Zafarqand index is located of $89 \mathrm{~km} \mathrm{NE}$ of Isfahan center, $22 \mathrm{~km} \mathrm{~S}$ of Ardestan city and $6 \mathrm{~km} \mathrm{~W}$ of Zafarqand village on the Urumieh-Dokhtar volcanic arc. The Kahang deposit is also located at $73 \mathrm{~km} \mathrm{NE}$ of Isfahan center and on Urumieh-Dokhtar volcanic arc. Tectonic point of view there has been located at the intersection of the Urumieh-Dokhtar volcanic arc and the some part of the Doruneh fault with the NE-SW trend.

The mentioned index and deposit are located at the edge of the central Iranian zone and the UrumiehDokhtar volcanic arc, so the presence of copper or other elements are potential. The lithology units of this index are mainly dacite porphyry, andesite, basalt, locally diorite and alluvial. The major of these rock units were affected by highly altered hydrothermal solutions and the alteration zones were created from the center of the porphyry system to the margins, respectively, include phyllic, argillic, propylitic and also potassic alterations could be seen in some parts of the area. Fe-hydroxides (i.e.; hematite, goethite) are observed in most places associated with central alterations. quartz-stockworks and veins and quartzmagnetite gouge in joints and fractures are found in many points related to copper mineralization (malachite and azurite) (Fig. 2).

\section{Prepare Your Paper Before Styling}

\section{Petrology of Zafarghand Index and Kahang Deposit}

The main rock units in Zafarghand porphyry copper index are mainly andesite, Dacite porphyry, Rhyodacit, quartz diorite and diorite, with quartz-magnetite veins and phyllic (quartz-sericite), argillic (quartz-clay minerals), propylitic (Chlorite-epidote) alterations and various types of Fe-oxide (hematite) and Fe-hydroxides (Jarosite and goethite). Alterations from the center of the porphyry system to the margins, respectively, include phyllic or quartz-sericite (mainly in the center of the southern and northern porphyry systems), quartzmagnetite stockworks (mainly in southern porphyry system), argillic (quartz-kaolinite) and propylitic alteration (epidote, chlorite in margins). Fe-hydroxides (i.e.; hematite, goethite) are observed in most places in relation to phyllic and argillic alterations.

The original matrix of the Rhyodacit as main rock unit is strongly influenced by the phenomenon of sericite and clay and represents the process of the phyllic and argillic alterations, so the original composition of the rock has not been recognized. However it can be assumed that this rock is probably a Rhyodacit, which were affected by the condition of silicification and the silica veins with were formed extensively. After the phenomenon (silicification), the copper (malachite) and also the goethite in between quartz crystals were also composed in vein forms (Fig. 3).

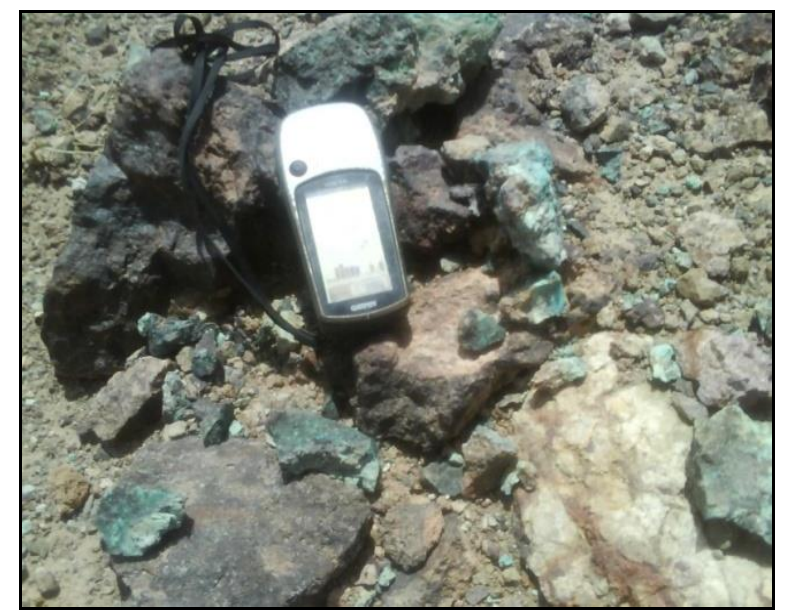

Fig. 2: Quartz and malachite veins in Zafarghand index (Asadi Haroni, 2010)

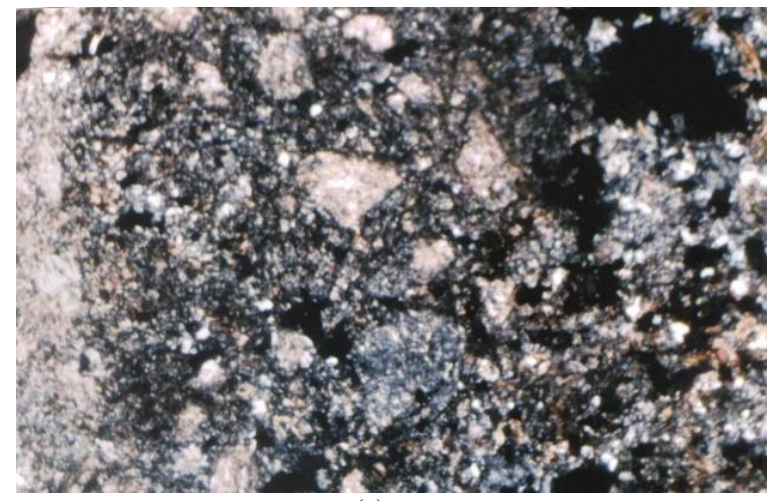

(a)

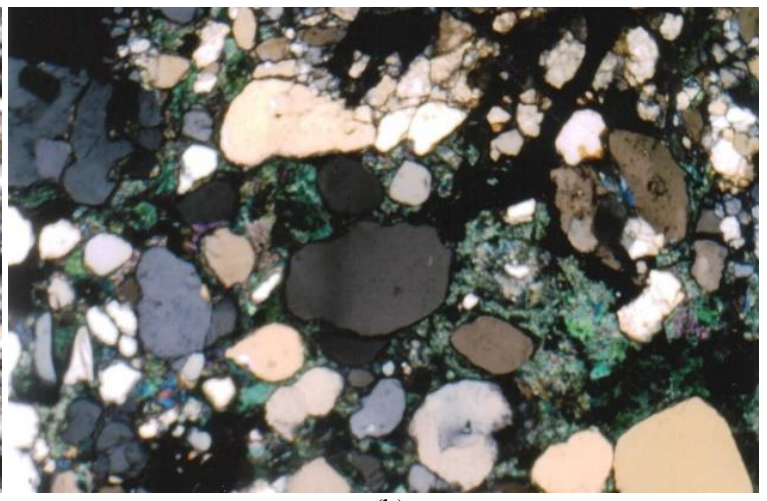

(b) 


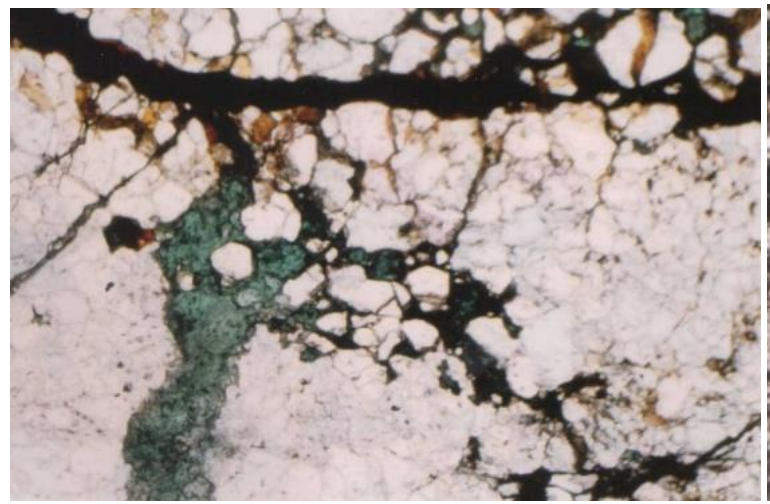

(c)

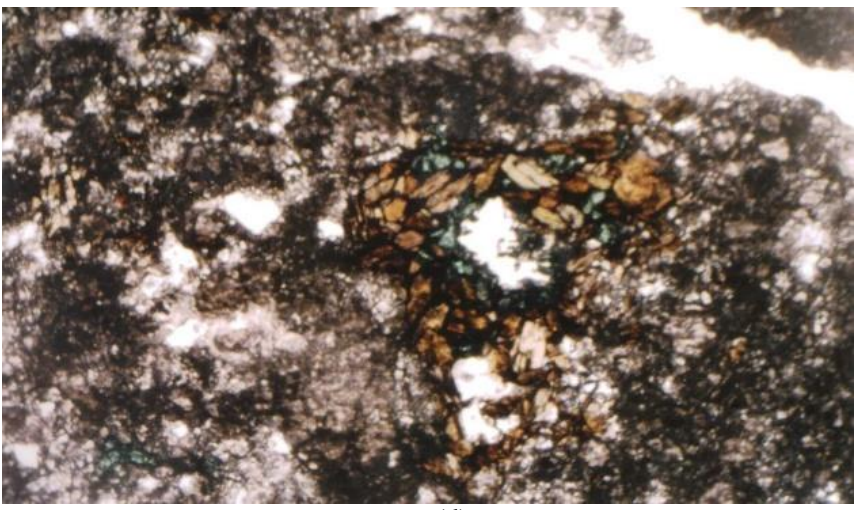

(d)

Fig. 3: Microscopic images of (magnified $\times 40$ in $x p l$ ) (a) malachite forming in quartz crystals of a silica vein in the matrix of the Rhyodacit, (b) the phenomenon of sericite and clay from feldspars in matrix, as the phenocrysts, (c) the formation of secondary Biotite crystals with malachite around the voids in the Rhyodacit, (d) Malachite, goethite and minerals indicate a delay phase in their formation relative to the matrix (Rhyodacit) (Mansouri Esfahani, 2010)

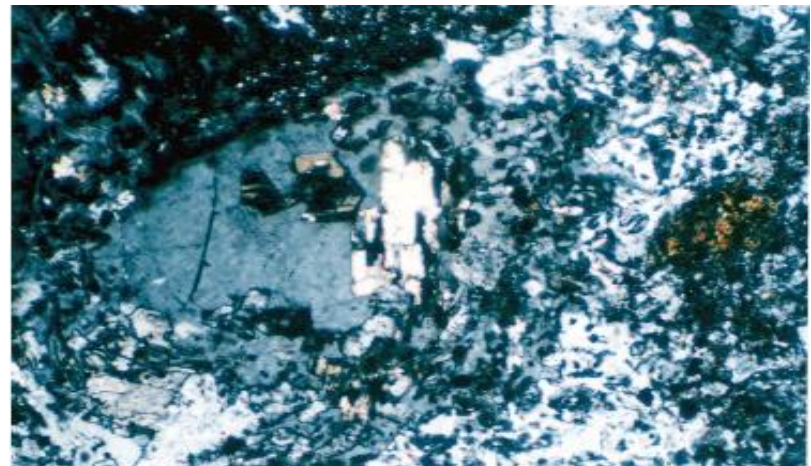

(a)

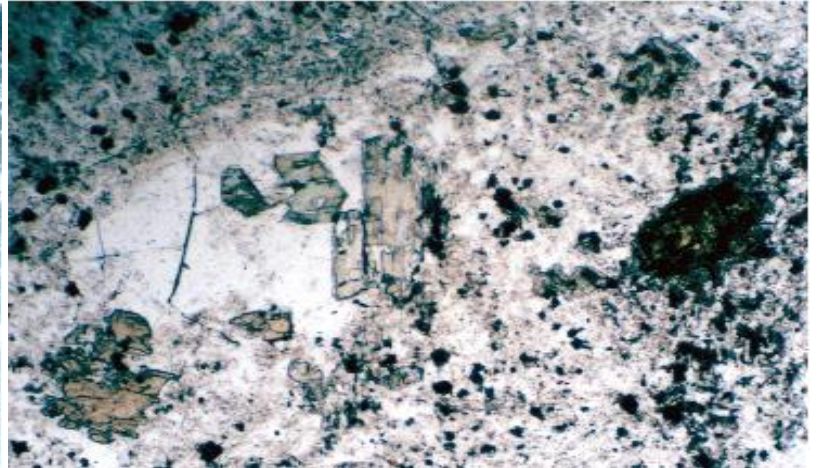

(b)

Fig. 4: Microscopic images, (a) amphibole crystals and plagioclase in the matrix of andesite microcrystalline, chloride phenomenon in all sections and epidotization of amphibole in the right side (propylitic alteration) is well observed; (b) hornblende residues undergoing chlorite and epidotization in andesite, which indicates propylitic alteration (Mansouri Esfahani, 2003)

The main rock units in the western deposit of Kahang porphyry copper are mainly andesite, andesite porphyry, dacite porphyry, quartz-monzonite, diorite and breccia andesite with quartz-magnetite veins and phyllic alterations (quartz-sericite), argillic (quartzclay Minerals), propylitic (epidote, chlorite) and all kinds of Fe-oxide (hematite) and Fe-hydroxides (Jarosite and goethite). The main rock units in the eastern part of Kahang deposit include andesite, andesitic breccia tuff (volcanic breccia), andesite porphyry, dacite Porphyry, quartz-monzonite, diorite, pebble dikes, along with quartz-magnetite veins and silica, phyllic, Argilic, propylitic alterations and $\mathrm{Fe}-$ oxide (hematite) and Fe-hydroxides (Jarosite and goethite) (Asadi Haroni, 2007) (Fig. 4). The composition of Miocene stock, ranges from diorite through granodiorite to quartz-monzonite. Field observations and petrographic studies show that the emplacement of the Kahang stock occurred in several pulses, each associated with its related hydrothermal activity (Afshooni et al., 2013). The primary magnetite grains having irregular boundaries formed in association with phyllic-potassic altered zones (Afshooni et al., 2014). Furthermore, there is evidence of potassic alteration to the west of Kahang. The dacite and rhyodacite volcanic rocks and graniticgranodioritic stocks have been experienced phyllic alteration. Disseminated and stockwork siliceous veins are the major styles of mineralization in this zone. Intermediate argillitic alteration developed on a part of dacitic and rhyodacitic rocks whereas andesite and basaltic-andesite plus related pyroclastic rocks have been subjected to propyllitic alteration. Hematite, goethite, jarosite, malachite and azurite are the predominant minerals of supergene zone. Pyrite is the most common hypogene sulfide mineral and chalcopyrite is the predominant $\mathrm{Cu}$ - sulfide in the Kahang mineralized area (Komeili et al., 2016). 


\section{Geochemical Model of Zafarghand Index and Kahang Deposit of Porphyry Copper- Molybdenum}

Geochemical studies are important, especially for ore deposits that enjoy larger halos than the ore deposits by themselves. These halos can be made due to depletion or enrichment of the elements. Investigations of genesis and extent of mineralization zone at surface and depth are also possible with geochemical information. In the common geochemical model of porphyry coppermolybdenum deposits, an anomalous ring of coppermolybdenum in the central part of the anomaly could be found and around it especially at margin of the altered halo, the manganese, silver, zinc, lead, cadmium and bismuth anomalies could be appeared (Hassanipak, 2008). Due to the fact that, some of the elements are less than the detection limit of the device, the data of these elements were removed from the data as outlier values. These elements include $\mathrm{Be}, \mathrm{Bi}, \mathrm{Cd}, \mathrm{B}, \mathrm{Ga}$, Te, $\mathrm{Hg}, \mathrm{Tl}, \mathrm{U}, \mathrm{W}$ and so on. The process of geochemical modeling are drawing in form of flow chart in Fig. 5. In geochemical studies, the distribution of various elements and compounds in Zafarghand index and Kahang deposit of porphyry copper-molybdenum were determined. The distribution of most existing elements corresponds to the log-normal distribution. For example, in the Zafarghand index, the range of copper element fluctuates from $0.1 \mathrm{ppm}$ to $17002 \mathrm{ppm}$ and the distribution is asymmetric and abnormal, which can be converted using by three-parametric of log-normal distribution ( $\log (\mathrm{Cu}-0.833))$ that could be normalized (Fig. 6 and 7). The probability diagrams of the elements are also drawn in Fig. 8, according to the Kolmogorov-Smirnov test the element has a nearly normal distribution in Zafarghand index and Kahang deposit of porphyry copper-molybdenum.

As shown from Fig. 5, firstly probability distribution function of elements were obtained; moreover, threshold values are calculated to separate anomalies from background using detachable statistics methods based on the probability distribution function and correlation between chemical elements in order to clustering themhave been investigated. Eventually the anomaly maps of single and composite halos of copper andmolybdenum were depicted to assign the enrichment zones in both Zafarghand index and Kahang deposit.

As could be seen from Fig. 6, all statistic parameters of copper element such as mean, standard deviation, variance, skewness, kurtosis and so on were calculated. It is evident that all of distribution enjoy the positive skewness, however in the normal distribution the skewness should be zero. The data in order to have standard distribution, were converted to three-parametric log-normal (Fig. 7).

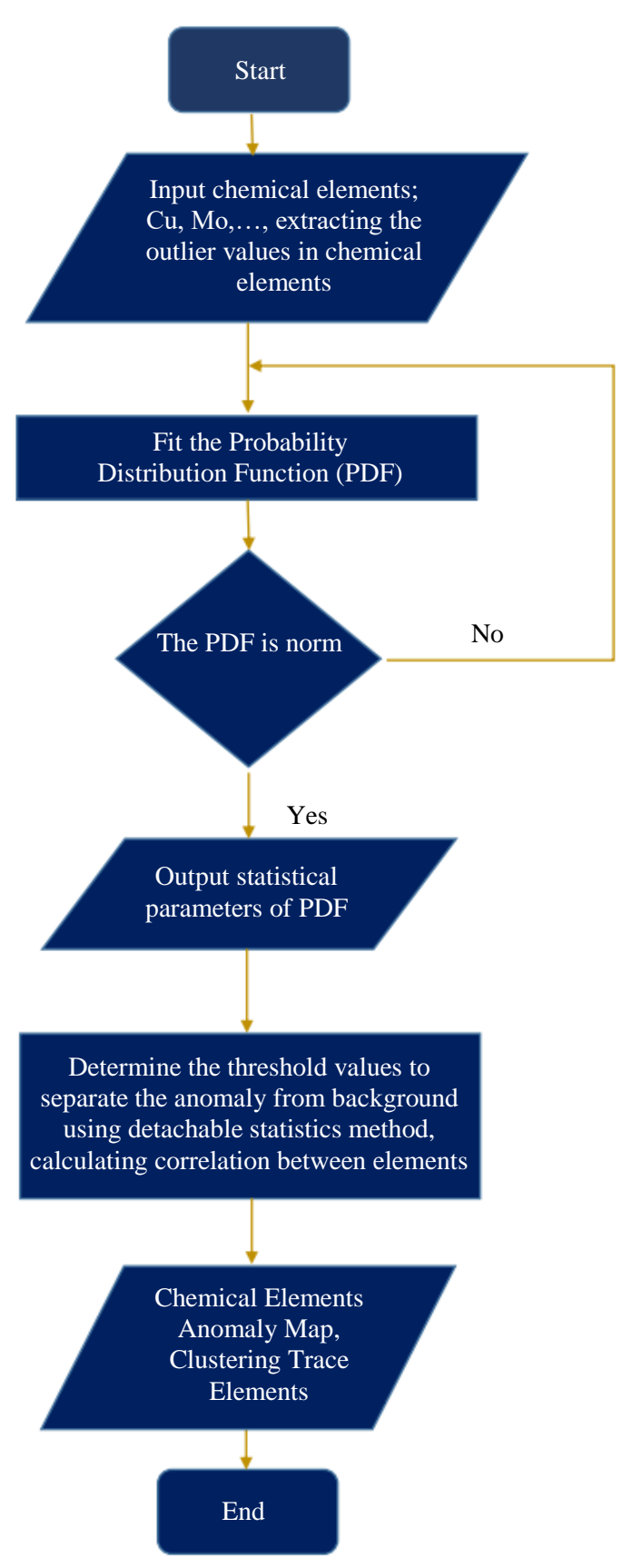

Fig. 5: The process of geochemical modeling in form of flow chart

The three-parametric of log-normal distribution of copper with a nearly zero and three in skewness and kurtosis, respectively, are depicted in Fig. 7. Furthermore, the converted data also should be draw in probability plot and as can be seen from Fig. 8, the data are arranged by nearly straight lines, justifying the normal distributions of copper element in both Zafarghand index and Kahang deposit of porphyry copper-molybdenum. 
Mohsen Dehghanipoodeh et al. / American Journal of Engineering and Applied Sciences 2020, 13 (4): 683.698 DOI: 10.3844/ajeassp.2020.683.698

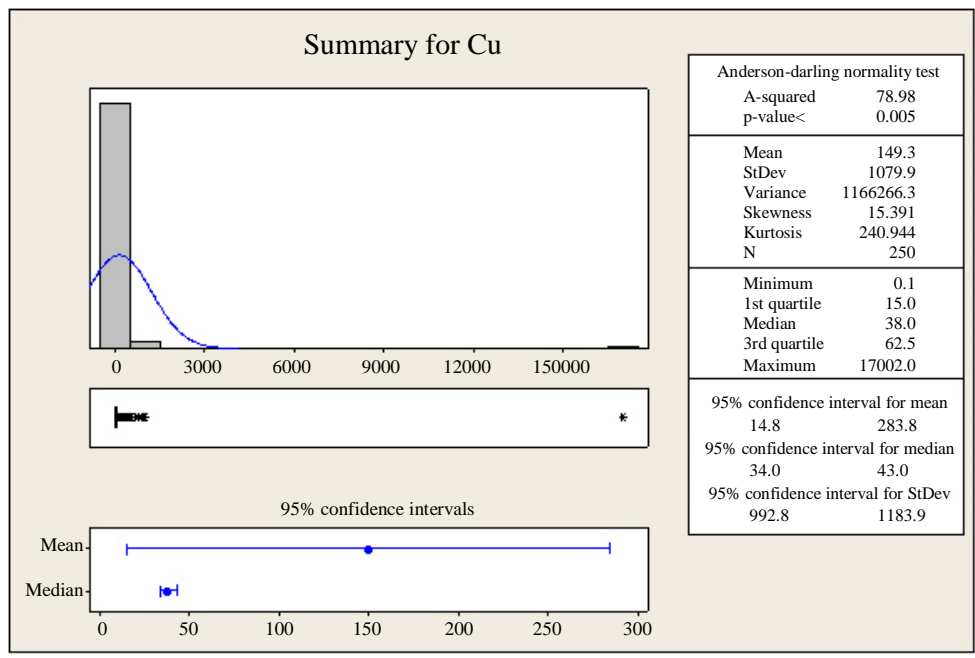

(a)

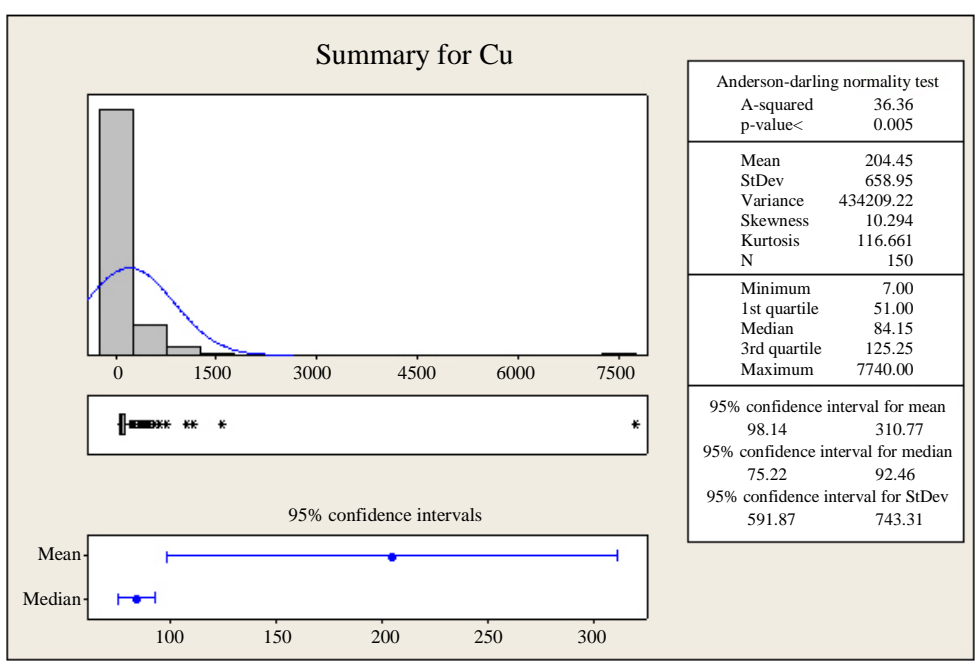

(b)

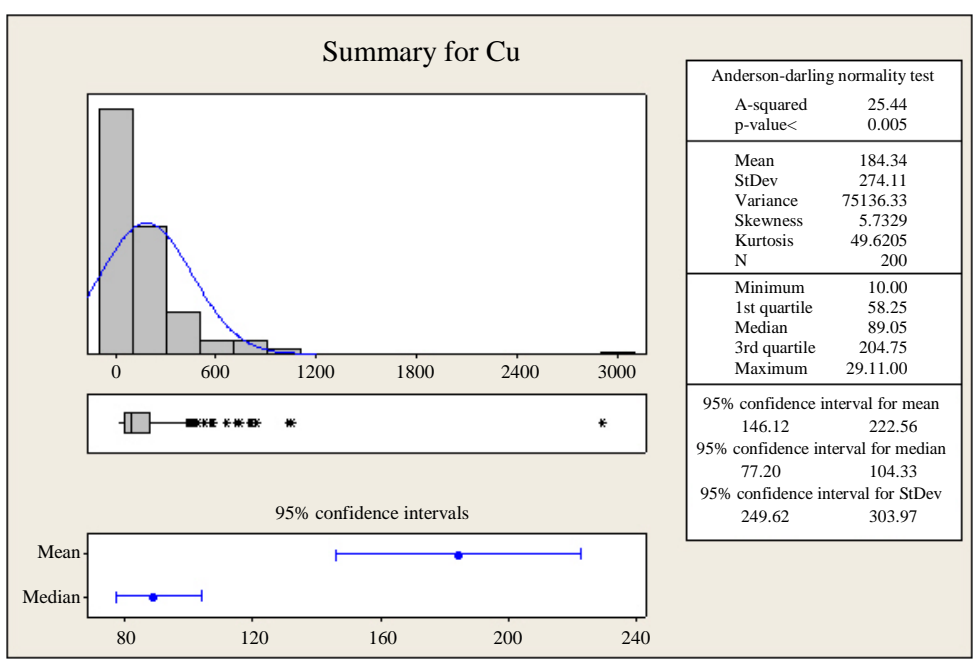

(c)

Fig. 6: Distribution diagram of copper element (in ppm); (a) Zafarghand index, (b) western part and (c) eastern part of Kahang deposit 


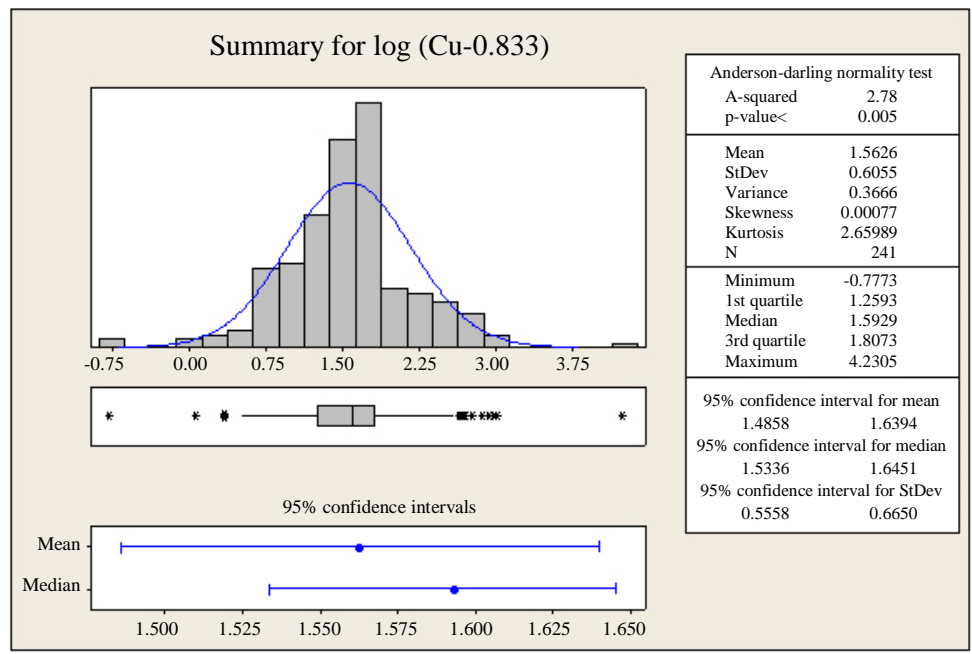

(a)

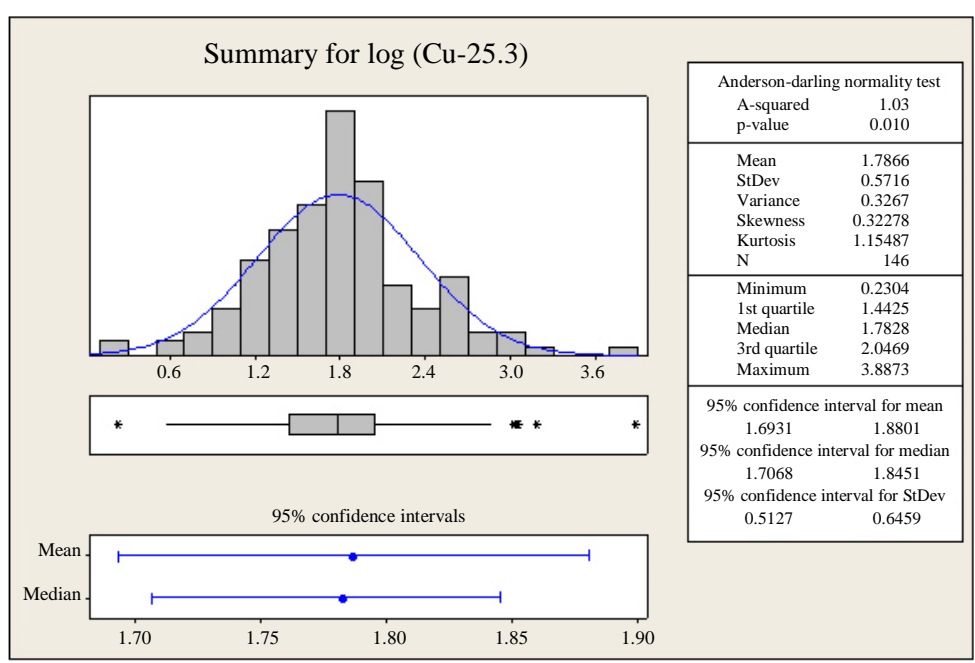

(b)

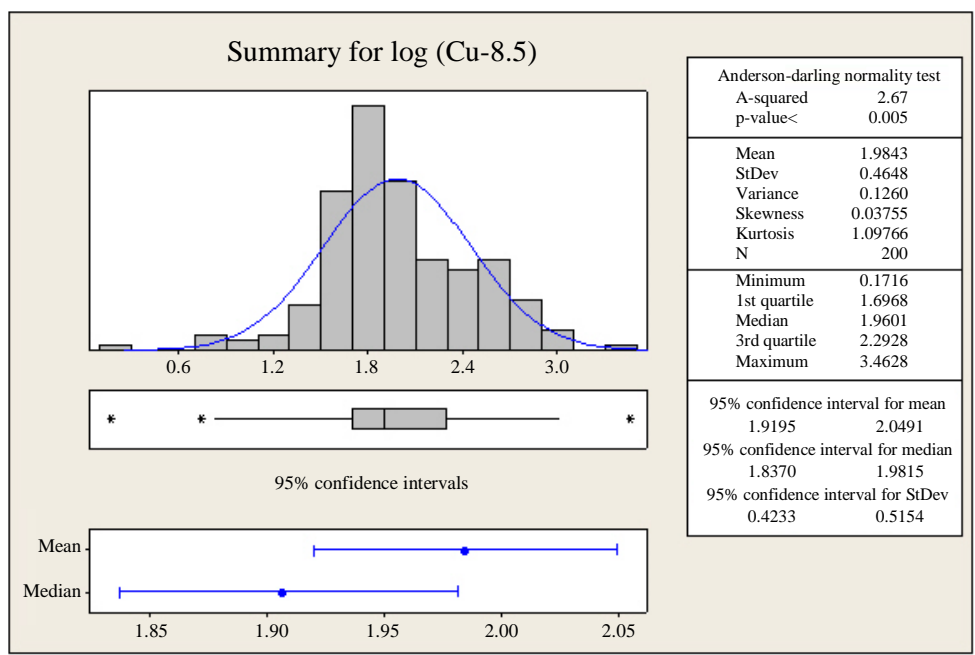

(c)

Fig. 7: The three-parameteric of log-normal distribution diagram of copper element (in ppm); (a) Zafarghand index, (b) western part and (c) eastern part of Kahang deposit 


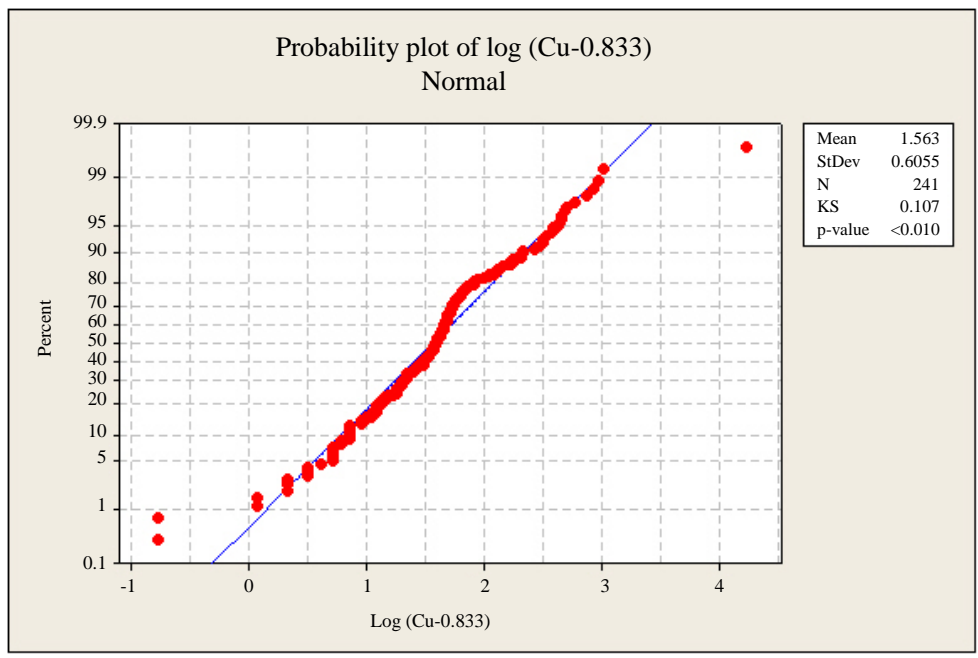

(a)

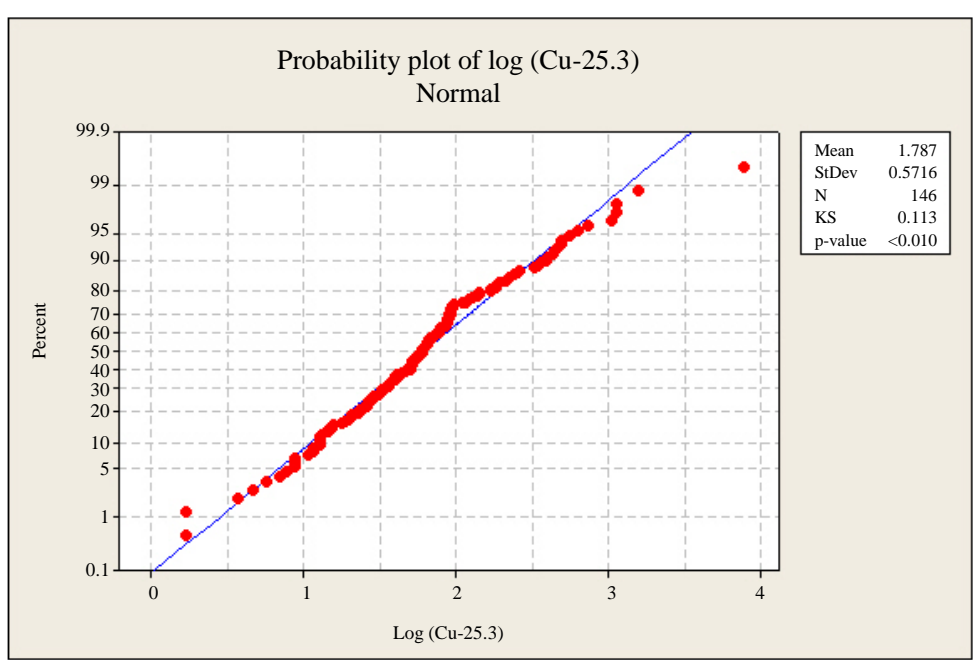

(b)

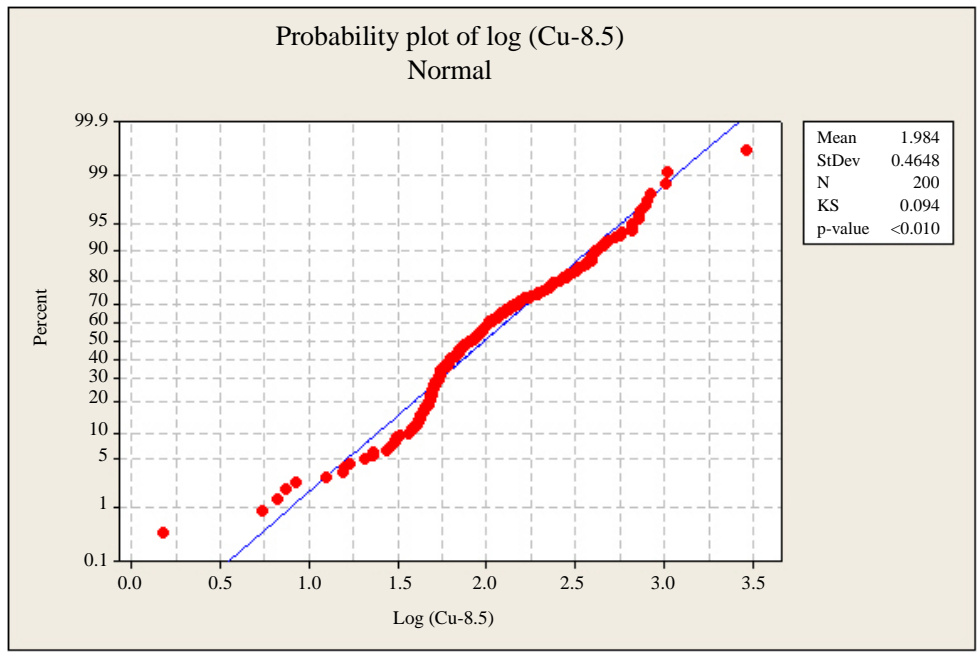

(c)

Fig. 8: The probability diagram of the copper element (in ppm); (a) Zafarghand index, (b) western part and (c) eastern part of Kahang deposit 


\section{Determine the Threshold Values to Separate the Anomaly from Background}

Detachable statistics are one of the methods based on the distribution function, which can be used to estimate the threshold values (the separation range of the anomaly from the background) (Hassanipak and Sharafodin, 2005). The first step in this method is to find the transformation of the data that approaches the distribution of data as much as possible to the normal distribution, since this method is based on the assumption of the normal distribution of data. Next, the converted data is sorted in terms of their values and should be standardize them to eliminate the scale effects, so that the mean and standard deviation of each element should be zero and one, respectively. The standardized data is called $\mathrm{Z}$. The amount of detachable statistics for each pair are calculated in 3 steps as follows:

1. Calculation of the mean value of two standardized sequential values $\left(m_{i}\right)$ :

$$
m_{i}=\frac{Z_{i+1}+Z_{i}}{2}
$$

2. Determination of the detachable value $\left(G_{i}\right)$ :

$$
G_{i}=0.3989 * e^{\left(-\frac{1}{2} m_{i}^{2}\right)} *\left(Z_{i+1}-Z_{i}\right)
$$

3. In the end the mi, related to largest amount of detachable statistics is specified and the threshold value could be specified by the following equation:

$$
C_{a}=10^{\left(\overline{\log X}+m_{i}^{*} S_{\log }\right)}
$$

The threshold value of copper, molybdenum, lead and zinc elements has been calculated by the abovementioned method, the results of are given in the Table 1-3 (Safi Khani et al., 2010).

Figure 9 and 10 show maps of single-element halos for copper, manganese in soil and rock samples, in which copper anomalies (threshold values) are separated from background with thicker contour lines.

Table 1: Threshold value copper, molybdenum, lead and zinc elements in Zafarghand index

\begin{tabular}{lll}
\hline Element & Threshold value $(\mathrm{ppm})$ & $m_{i}$ \\
\hline $\mathrm{Cu}$ & 129.89 & 0.90538 \\
$\mathrm{Mo}$ & 11.557 & 0.02113 \\
$\mathrm{~Pb}$ & 77.460 & 0.94633 \\
$\mathrm{Zn}$ & 161.27 & 0.62971 \\
\hline
\end{tabular}

Table 2: Threshold value copper, molybdenum, lead and zinc elements in western part of Kahang deposit

\begin{tabular}{lcr}
\hline Element & threshold value $(\mathrm{ppm})$ & \multicolumn{1}{c}{$m_{i}$} \\
\hline $\mathrm{Cu}$ & 178.400 & 0.69188 \\
$\mathrm{Mo}$ & 10.118 & 82.61900 \\
$\mathrm{~Pb}$ & 114.000 & 1.04075 \\
$\mathrm{Zn}$ & 141.950 & 0.43611 \\
\hline
\end{tabular}

Table 3: Threshold value copper, molybdenum, lead and zinc elements in eastern part of Kahang deposit

\begin{tabular}{lll}
\hline Element & threshold value $(\mathrm{ppm})$ & $m_{i}$ \\
\hline $\mathrm{Cu}$ & 123.112 & 0.16121 \\
$\mathrm{Mo}$ & 21.000 & 1.49779 \\
$\mathrm{~Pb}$ & 64.514 & 0.84069 \\
$\mathrm{Zn}$ & 248.000 & 1.34269 \\
\hline
\end{tabular}

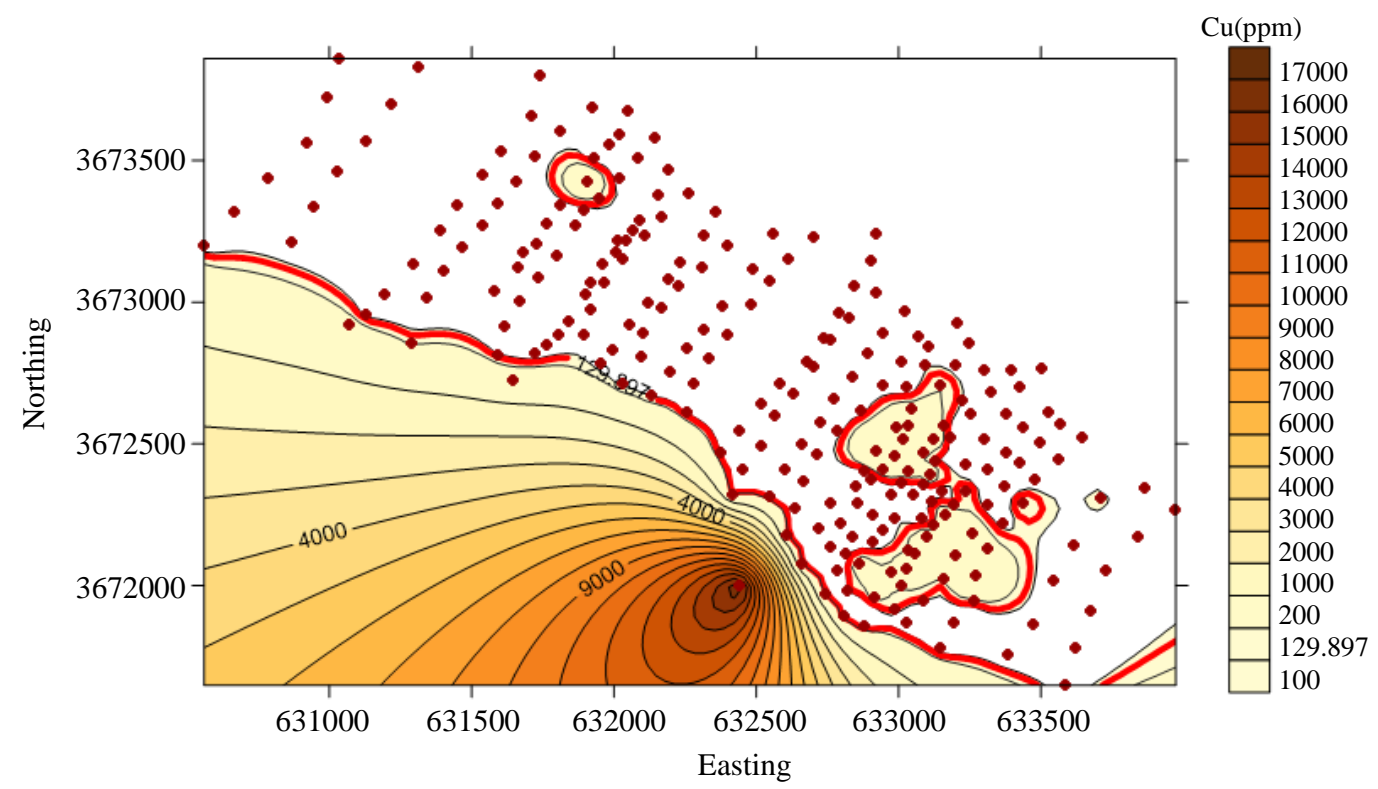

(a) 
Mohsen Dehghanipoodeh et al. / American Journal of Engineering and Applied Sciences 2020, 13 (4): 683.698 DOI: 10.3844/ajeassp.2020.683.698

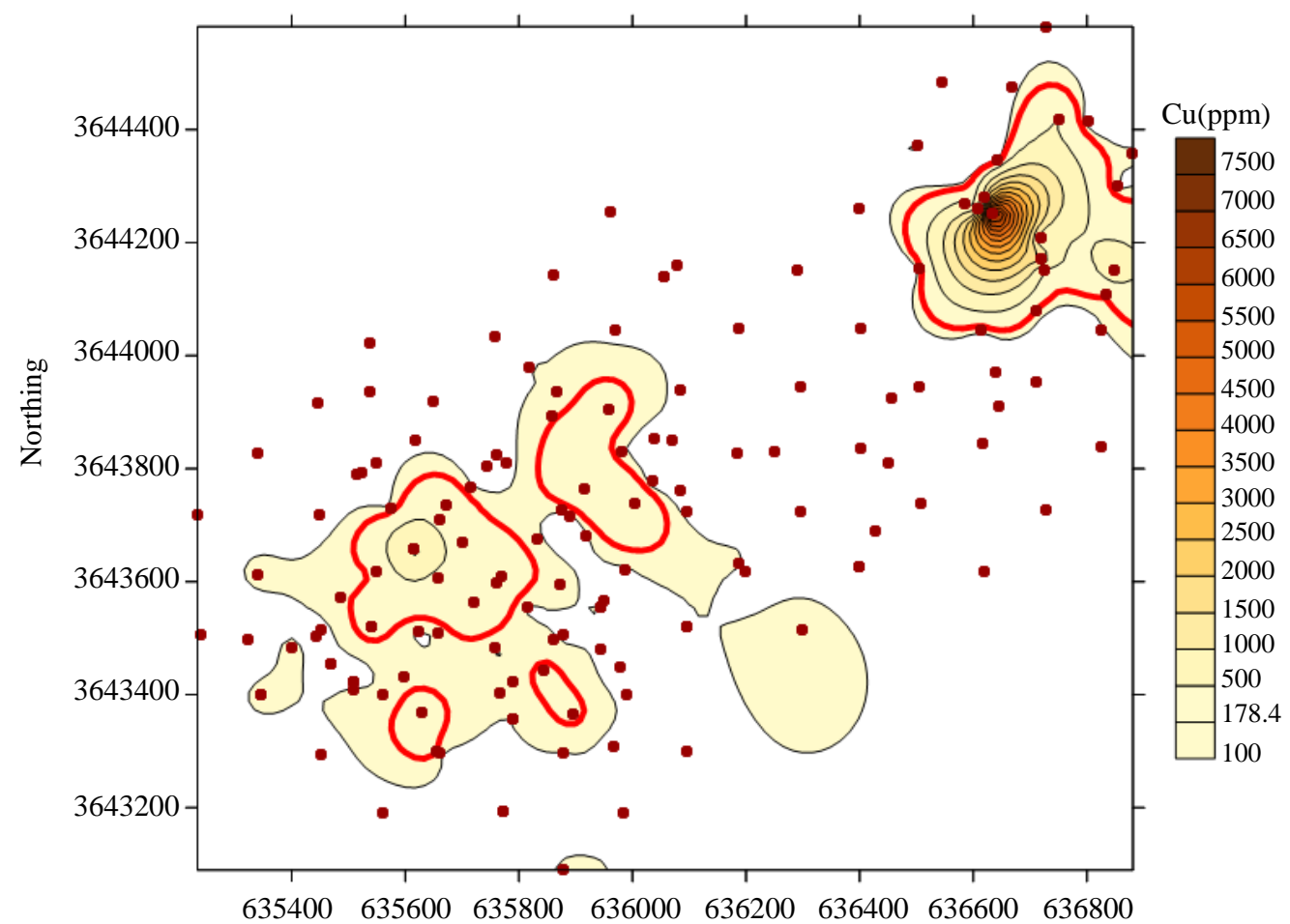

Easting

(b)

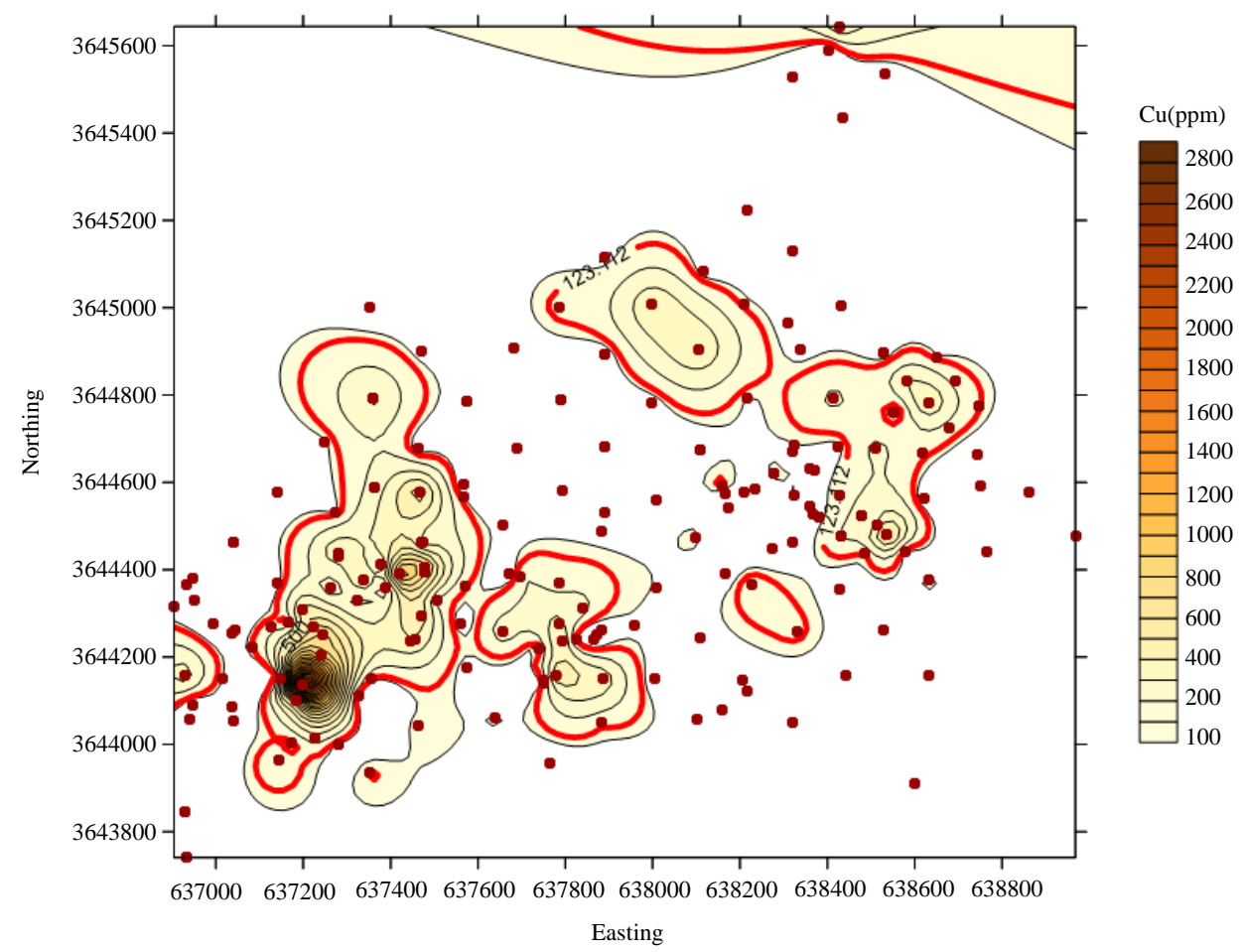

(d)

Fig. 9: The copper element anomaly map (in ppm); (a) Zafarghand index, (b) western part and (c) eastern part of Kahang deposit 
According to the above maps in Fig. 9 and 10, copper anomalies are existed in elsewhere the manganese's are depleted. In order to find this reason the correlation between elements should be calculated.

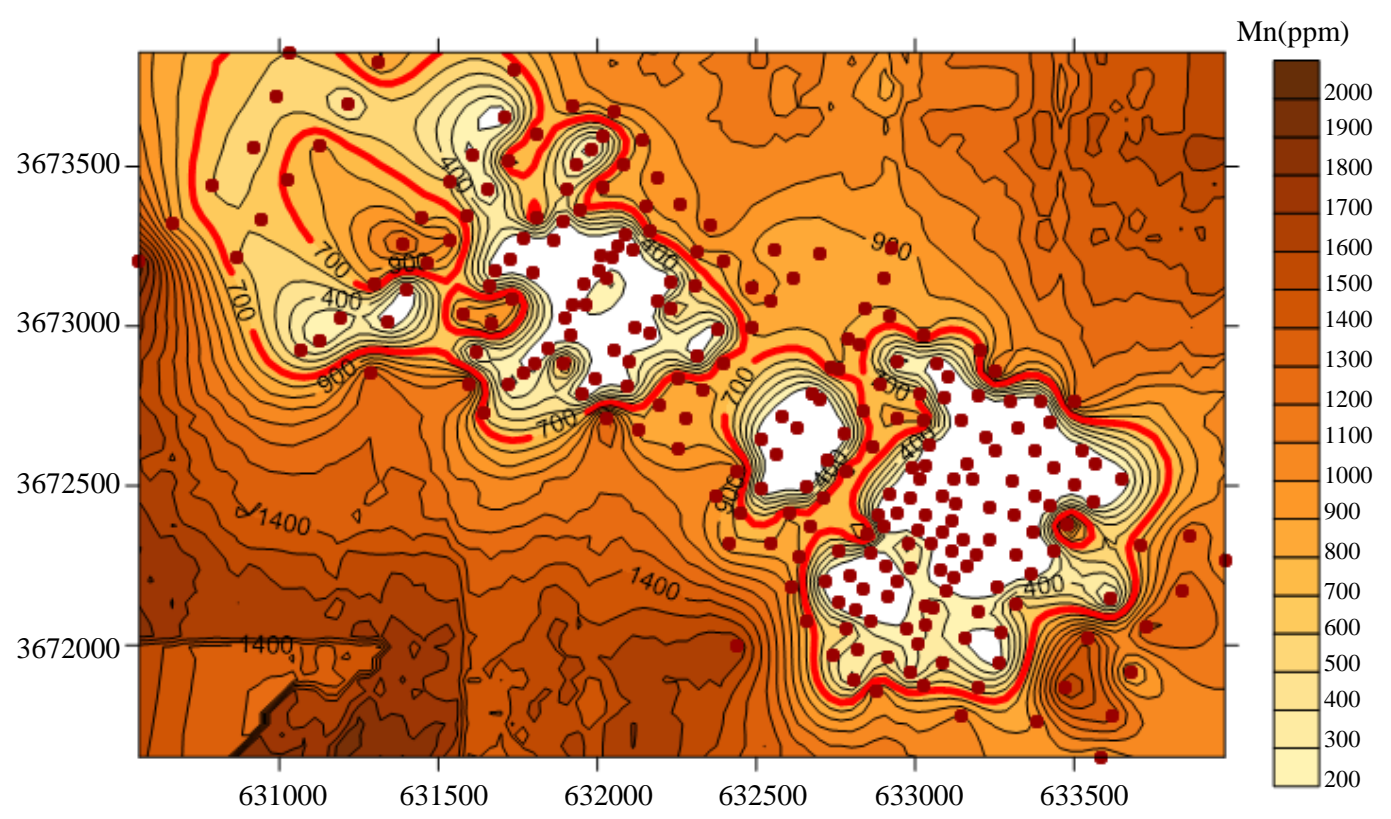

(a)

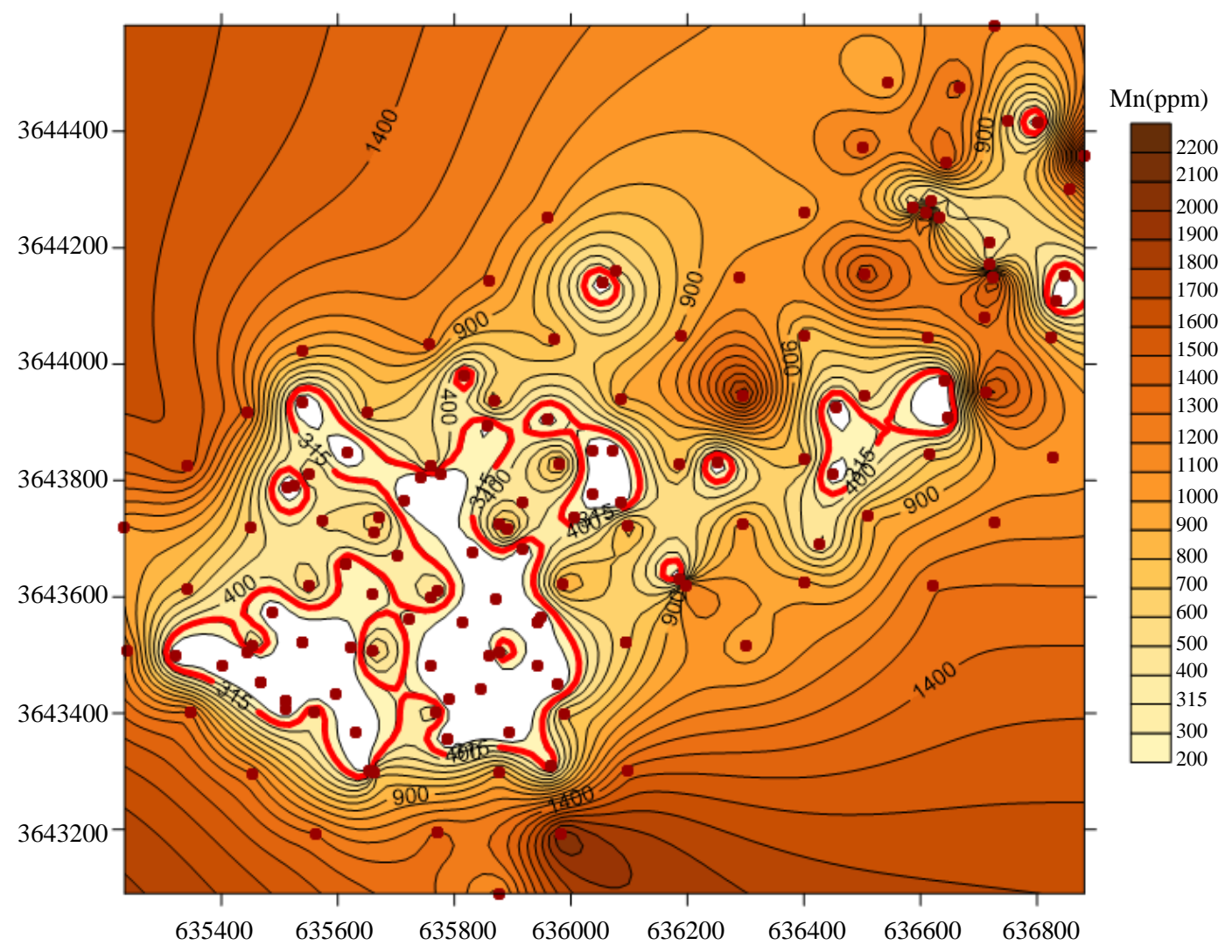

(b) 


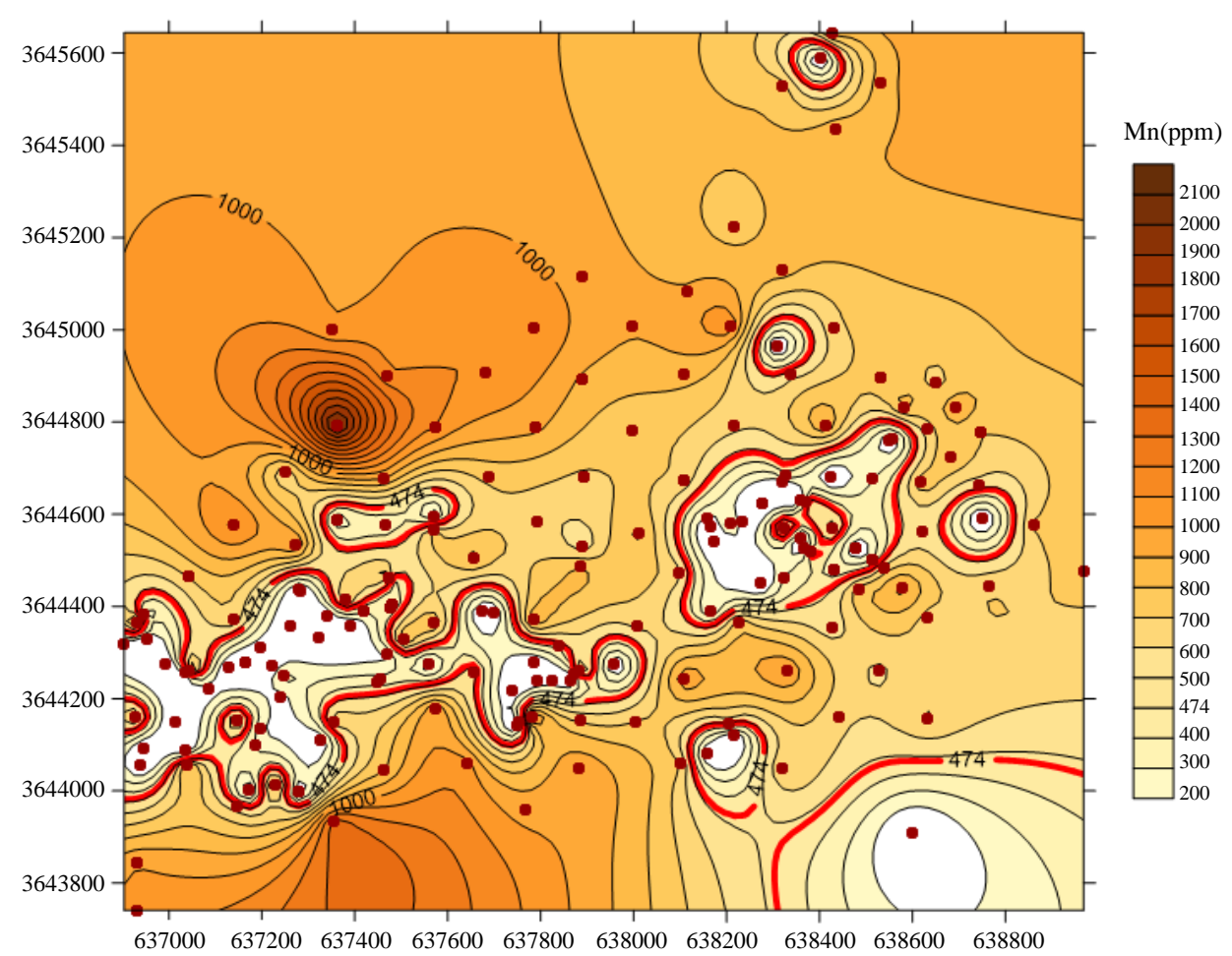

(c)

Fig. 10: The manganese element anomaly map (in ppm); (a) Zafarghand index, (b) western part and (c) eastern part of Kahang deposit

\section{Correlation between Elements}

Pearson correlation coefficient is used to find the correlation between the elements. Therefore, the main condition of correlation in this method is the normal distribution (i.e., skewness and kurtosis are zero and three, respectively). For this purpose, elements obey the of the three-parameter log-normal distribution (Hassanipak and Sharafodin, 2005; Safi Khani et al., 2010). The Pearson correlation matrix are presented in Equation 4-6 associated with Zafarghand index, western and eastern part of Kahang deposit, respectively:

$\left.\begin{array}{ccccccccc}- & C u & M o & P b & Z n & A s & S b & M n & C d \\ C u & 1.000 & 0.499 & 0.115 & 0.228 & 0.431 & -0.239 & -0.167 & 0.405 \\ M o & 0.499 & 1.000 & 0.426 & 0.254 & 0.313 & -0.263 & -0.160 & 0.495 \\ \mathrm{~Pb} & 0.115 & 0.426 & 1.000 & 0.262 & 0.397 & -0.135 & 0.352 & 0.475 \\ \mathrm{Zn} & 0.228 & 0.254 & 0.262 & 1.000 & 0.569 & 0.062 & 0.547 & 0.615 \\ \mathrm{As} & 0.431 & 0.313 & 0.397 & 0.569 & 1.000 & -0.070 & 0.389 & 0.836 \\ \mathrm{Sb} & -0.239 & -0.263 & -0.135 & 0.062 & -0.070 & 1.000 & -0.155 & -0.505 \\ \mathrm{Mn} & -0.167 & -0.160 & 0.352 & 0.547 & 0.389 & -0.155 & 1.000 & 0.449 \\ \mathrm{Cd} & 0.405 & 0.495 & 0.475 & 0.615 & 0.836 & -0.505 & 0.449 & 1.000\end{array}\right]$

$$
\left[\begin{array}{ccccccccc}
- & C u & M o & P b & Z n & A s & S b & M n & C d \\
C u & 1.000 & 0.192 & 0.071 & 0.228 & 0.125 & -0.253 & -0.153 & 0.226 \\
M o & 0.192 & 1.000 & -0.061 & 0.122 & 0.091 & -0.080 & -0.178 & 0.234 \\
\mathrm{~Pb} & 0.071 & -0.061 & 1.000 & 0.304 & 0.145 & -0.082 & 0.334 & 0.330 \\
\mathrm{Zn} & 0.228 & 0.122 & 0.304 & 1.000 & 0.480 & -0.285 & 0.429 & 0.795 \\
\mathrm{As} & 0.125 & 0.091 & 0.145 & 0.480 & 1.000 & -0.111 & 0.239 & 0.740 \\
\mathrm{Sb} & -0.253 & -0.080 & -0.082 & -0.285 & -0.111 & 1.000 & -0.774 & -0.024 \\
\mathrm{Mn} & -0.153 & -0.178 & 0.334 & 0.429 & 0.239 & -0.774 & 1.000 & -0.095 \\
\mathrm{Cd} & 0.226 & 0.234 & 0.330 & 0.795 & 0.740 & -0.024 & -0.095 & 1.000
\end{array}\right] \text { (6) }
$$

According to Equation 4-6, the copper and molybdenum elements have a positive and fairly high correlation coefficient, while the elements have a negative correlation with manganese, which is a evidence to exist copper-molybdenum deposit by itself.

\section{Clustering Elements}

In the Ward's method, the criterion of connecting an object to a cluster or two clusters to each other which are creating the least increase in the summation of squared deviation of average in the desired cluster. The results of this method are suitable for the appearance and maintenance of the construction hierarchy. For this reason, this method has been identified as an appropriate choice in cluster analysis and in this methods, the correlation coefficient has been used as a similarity criterion (Hassanipak and Sharafodin, 2005; Safi Khani et al., 2010). At this stage, it has been tried to use the main elements of the deposit and other above-deposit elements which they enjoy more mobility than copper and 
Mohsen Dehghanipoodeh et al. / American Journal of Engineering and Applied Sciences 2020, 13 (4): 683.698 DOI: 10.3844/ajeassp.2020.683.698

molybdenum. As copper shows good correlation with molybdenum in all Equation 1-3, so in order to confirm this correlation, cluster analysis was drawn using Pearson's coefficient of correlation (Fig. 10).

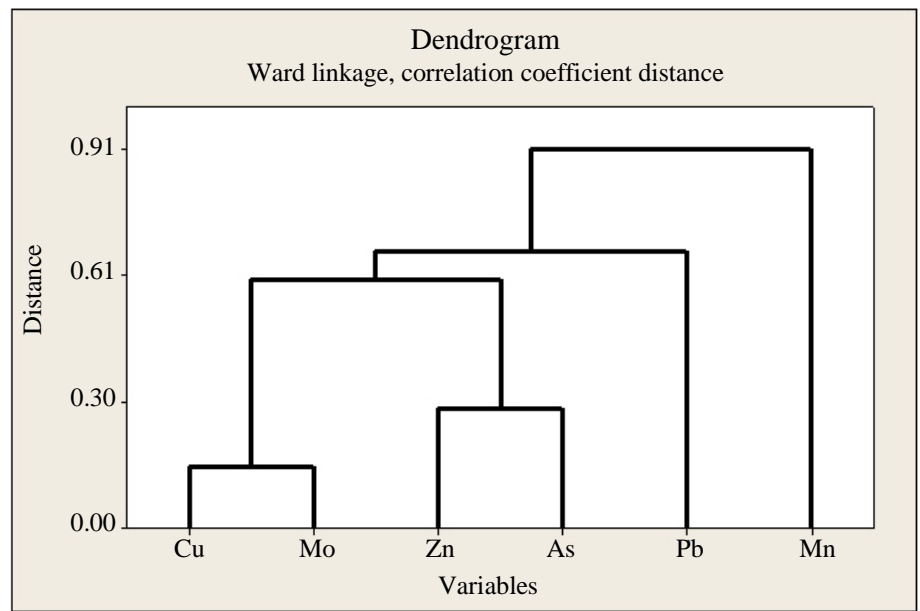

(a)

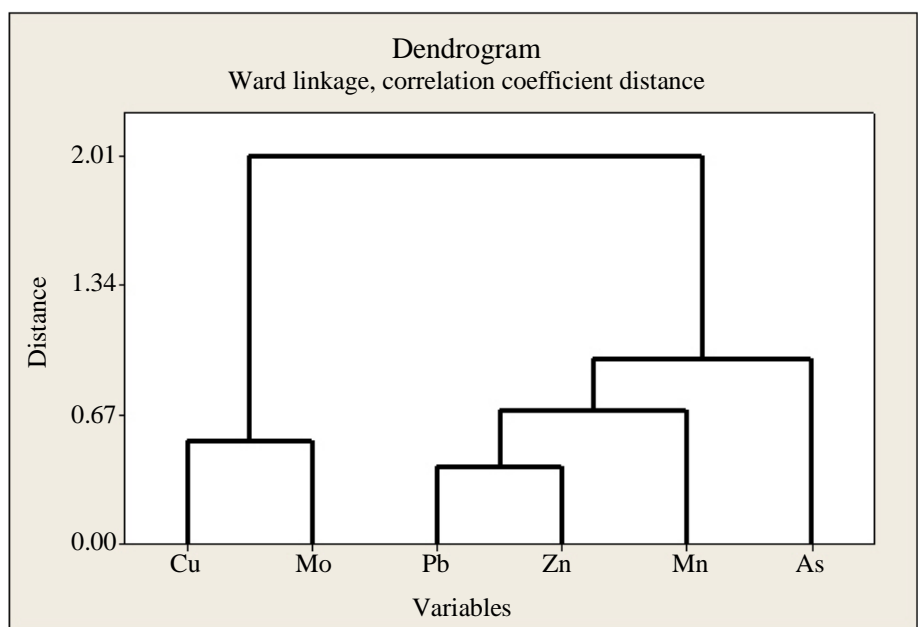

(b)

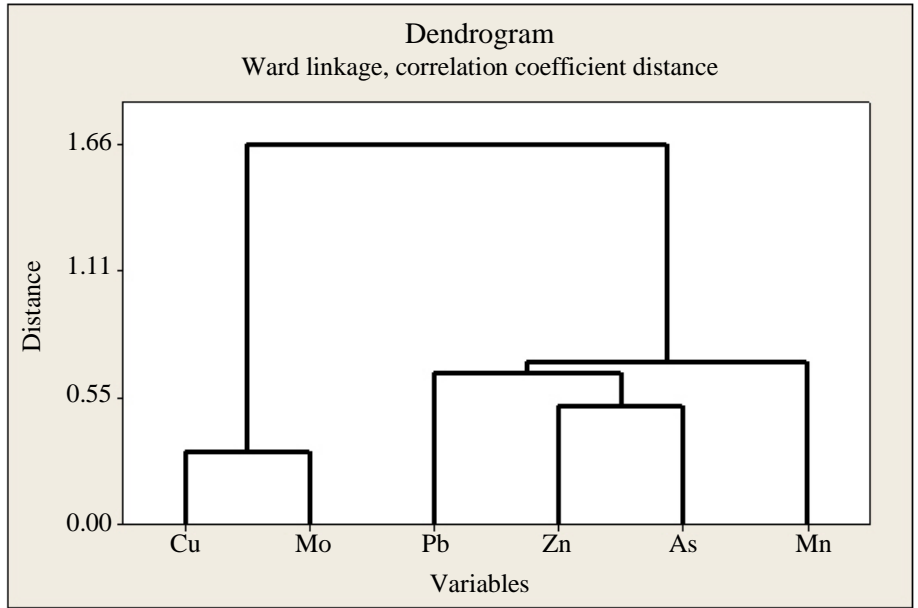

(c)

Fig. 11: The cluster analysis of trace elements in the exploration of copper halos in; (a) Zafarghand index, (b) western part and (c) eastern part of Kahang deposit 
As can be seen from Fig. 11, the elements that are presented in the center of mineralization system (i.e.; $\mathrm{Cu}$, Mo) are placed in the same category and the marginal elements of the ore deposit (above deposit), which are more mobile, located in the other categories and this is another evidence for existence the copper-molybdenum porphyry deposit.

\section{Composite Halo}

After calculating the correlation coefficient and performing the cluster analysis of the elements, since the copper and molybdenum elements were placed in a cluster, then this correlation could be presented in the form of a composite halo maps.
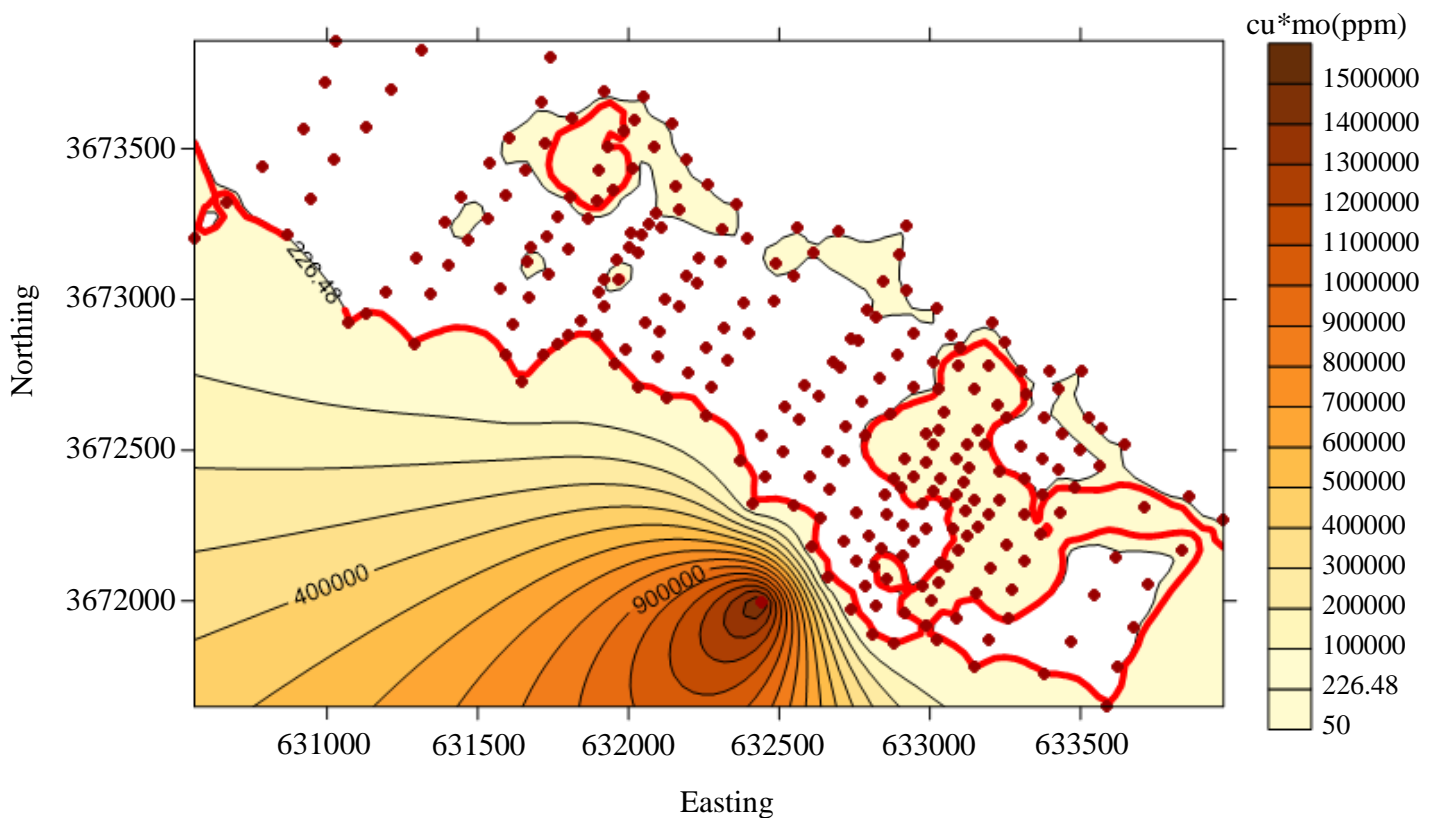

(a)

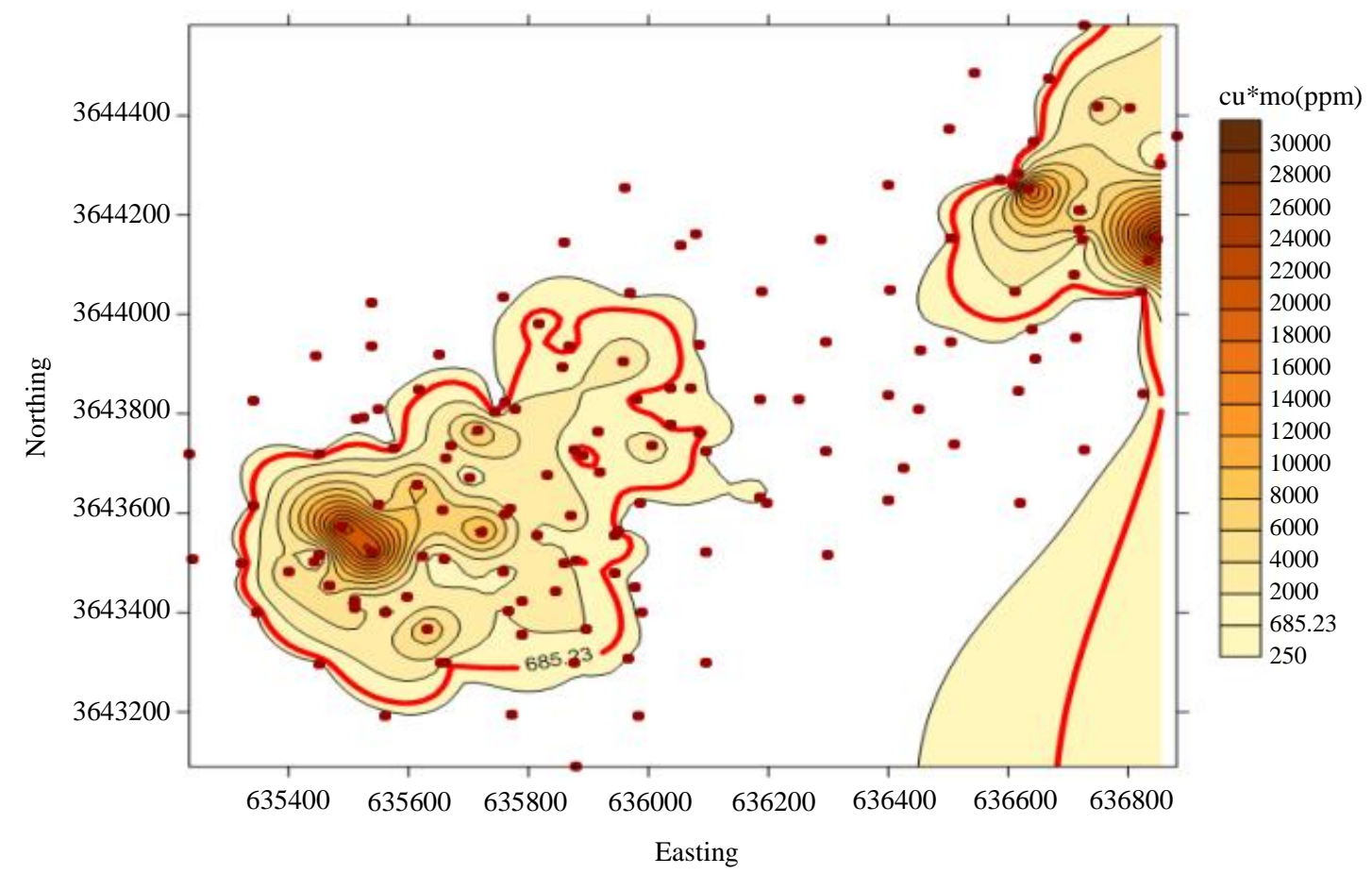

(b) 


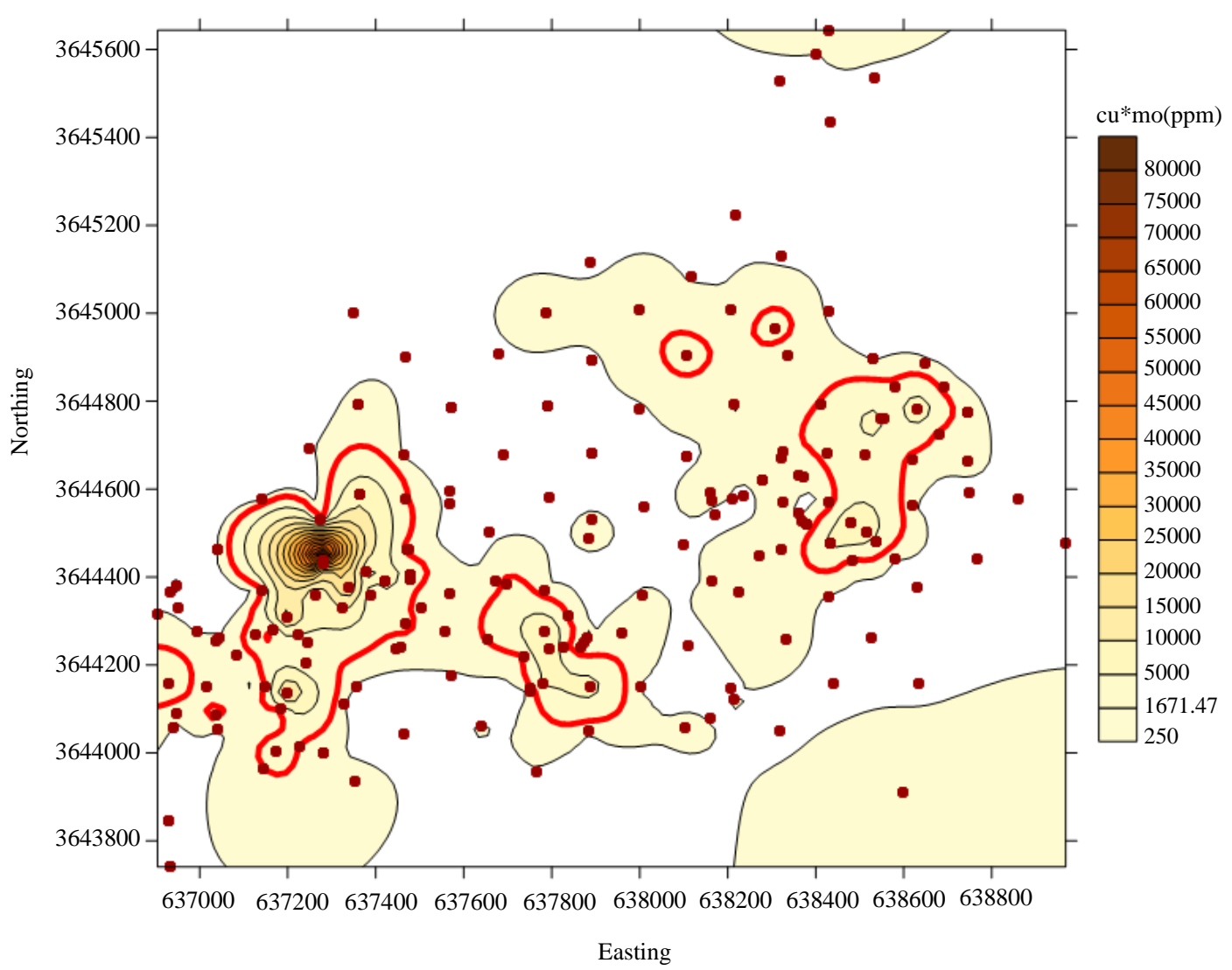

(c)

Fig. 12: The anomaly map of composite halo of copper and molybdenum in (in ppm); (a) Zafarghand index, (b) western part and (c) eastern part of Kahang deposit

By the comparison the Fig. 9 and 12, the composite halo of copper and molybdenum elements are extended in nearly same area and it is a verification of the positive correlation of two mentioned elements.

\section{Conclusion}

In this study, geological properties along with the geochemical properties such as study of geochemical anomalies of elements, determination of threshold values to separate anomalies from background using detachable statistics methods based on the probability distribution function and calculating correlation between chemical elements in order to clustering them have been investigated. Eventually the anomaly maps of single and composite halo of copper and molybdenum were depicted to assign the enrichment zones in both Zafarghand index and Kahang deposit. The conclusions are summarized as follows:

- Early geological evidence such as the type of rock units, alteration zoning (from the center to the margins including phyllic, argillic and propylitic alterations) indicates the characteristics of the porphyry copper-molybdenum deposits

- In geochemical studies, considering the presence of copper, molybdenum in a cluster and lead, zinc, manganese and arsenic in other cluster indicates the presence of copper-molybdenum mineralization in the region

- The concentration of copper and molybdenum in the central part and the second cluster elements on the margin of mineralization indicates the porphyry copper-molybdenum mineralization system

- The composite halo of copper and molybdenum elements are a verification of the positive correlation of two mentioned elements

\section{Acknowledgement}

The authors warmly acknowledge the head of optical mineralogy laboratory at Department of Mining Engineering, Isfahan University of Technology, Isfahan, Iran. 


\section{Funding Information}

All prior investigations in preparation this study were funded by Dorsa pardazeh company, Isfahan, Iran.

\section{Author's Contributions}

All authors equally contributed in this work.

\section{Ethics}

All rights of this study are owned Department of Mining Engineering, Isfahan University of Technology and Dorsa pardazeh company and should be maintained.

\section{References}

Afshooni, S. Z., Esmaeily, D., \& Asadi Haroni, H. (2014). Stable isotopes (S, H, O) study In phyllic and potassic-phyllic alteration zones of the Kahang porphyry copper-Molybdenum deposit (Northeast of Isfahan). Journal of Advanced Applied Geology, 1(7), 64-73.

Afshooni, S. Z., Mirnejad, H., Esmaeily, D., \& Haroni, H. A. (2013). Mineral chemistry of hydrothermal biotite from the Kahang porphyry copper deposit (NE Isfahan), Central Province of Iran. Ore Geology Reviews, 54, 214-232.

Afzal, P., Alghalandis, Y. F., Moarefvand, P., Omran, N. R., \& Haroni, H. A. (2012). Application of powerspectrum-volume fractal method for detecting hypogene, supergene enrichment, leached and barren zones in Kahang $\mathrm{Cu}$ porphyry deposit, Central Iran. Journal of Geochemical Exploration, 112, 131-138.

Afzal, P., Alghalandis, Y. F., Khakzad, A., Moarefvand, P., \& Omran, N. R. (2010). Application of power spectrum-area fractal model to separate anomalies from background in Kahang $\mathrm{Cu}-\mathrm{Mo}$ porphyry deposit, Central Iran. Archives of Mining sciences, 55(3), 389-401.

Aliani, F., Alirezaei, A., Moradian, A., \& Abbasloo, Z. (2009). Geochemistry and petrography of the Meiduk porphyry copper deposit, Kerman, Iran. Australian Journal of Basic and Applied Sciences, 3(4), 3786-3800.

Asadi Haroni, H. (2010). Geological and alteration map of Zafarghand Porphyry Copper-Molybdenum Index.

Asadi Haroni, H. (2003). Geological map and alteration of Kahang Porphyry Copper-Molybdenum Deposit.

Asadi Haroni, H. (2007). Detailed exploration in Kahang porphyry $\mathrm{Cu}-\mathrm{Mo}$ index. Dorsa Pardazeh Company, Isfahan, Report 3.

Darvishzadeh, A.S. (1991). Geological Survey of Iran. Today Nashr-dansh Press.
Derakhshani, R., \& Abdolzadeh, M. (2009). Geochemistry, mineralization and alteration zones of Darrehzar porphyry copper deposit, Kerman, Iran. Journal of Applied Sciences, 9(9), 1628-1646.

Hassanipak, A. (2008). Principles of geochemical exploration. Publishing and Printing Institute of Tehran University.

Hassanipak, A., \& Sharafodin, M. (2005). Exploration data analysis. Tehran University Press and Publishing Institute.

Karimpour, M. J., Malekzadeh, A., \& Heidariyan, M. R., (2005). Exploration of mineral resources. Ferdowsi University Press.

Komeili, S. S., Khalili, M., Asadi, H. H., Bagheri, H., \& Ayati, F. (2016). The nature of hydrothermal fluids in the Kahang porphyry copper deposit (Northeast of Isfahan) based on mineralography, fluid inclusion and stable isotopic data.

Kudrin, A. V., Varyash, L. N., Pashkov, Y. N., \& Rekharsky, V. I. (1986). The geochemical behaviour of copper and molybdenum in ore-forming processes. In Geology and Metallogeny of Copper Deposits (pp. 209-215). Springer, Berlin, Heidelberg.

Mansouri Esfahani, M. (2010). Mineralogy and petrography samples of Zafarghand Porphyry Copper-Molybdenum Index.

Mansouri Esfahani, M. (2003). Mineralogy and Petrography samples of Kahang Porphyry CopperMolybdenum Deposit.

Safi Khani, S., Asadi Haroni, H., \& Tabatabaei, H. (2010). Geochemical properties of the zafarghand porphyry copper-molybdenum index. Proceedings of the 29th Earth Science Conference.

Yasrebi, A. B., Afzal, P., Wetherelt, A., Foster, P. J., Esfahanipour, R., \& Parvaz, D. (2012). 3D Lithology, Alteration and Zonation Modelling of the Eastern Part of Kahang Cu-Mo-Au Porphyry Deposit in Central Iran. International Multidisciplinary Scientific GeoConference: SGEM, 1, 417.

Yasrebi, A. B., Afzal, P., Wetherelt, A., Foster, P., \& Esfahanipour, R. (2013). Correlation between geology and concentration-volume fractal models: significance for $\mathrm{Cu}$ and $\mathrm{Mo}$ mineralized zones separation in the Kahang porphyry deposit (Central Iran). Geologica Carpathica, 64(2), 153-163. 